\title{
Gibah Dalam Perspektif Hadis
}

\author{
Muhammad Fathul Amam \\ UIN Sultan Maulana Hasanuddin BANTEN \\ muhammadfathulamam@gmail.com
}

\begin{abstract}
This paper discusses ghibah in hadith perspective. Every human being is required to always do good, be kind, not hurt people, or gossip about others. But in fact Ghibah is now a common thing in today's society, it is not uncommon for us to find 2 or a group of people who are gossiping / gossiping. A small example is mothers who are being donated and even worse in the world of television, there are programs that are deliberately only for celebrity gossip and have a huge impact on life, including disputes. find out the authenticity of the hadith and also the syarah of the hadith, walaupu basically ghibah is haram but in that hadith there is a gain and no. This research uses library neset by fline and online. buy sayar in the complex, there must be something.
\end{abstract}

Key words: Ghibah, Hadith, sahih

\begin{abstract}
Abstrak
Tulisan ini membahas tentang ghibah dalam persfektif hadis. Setiap manusia dituntut untuk selalu berbuat baik, berbaik sangka, tidak menyakiti orang, ataupun menggunjing orang lain. Tapi pada kenyataannya Ghibah saat ini seperti sudah menjadi hal yang lumrah/biasa pada masyarakat sekarang, tidak jarang kita dapat menjumpai 2 atau pun sekumpulan orang yang sedang gosip/ghibah. Contoh kecilnya adalah ibu-ibu yang sedang membeli sayar dikomplek pasti ada saja yang dighibahkan dan lebih parahnya di dunia televisi sendiri ada acara-acara yang sengaja hanya untuk gosip para selebriti dan memiliki dampak terhadap kehidupan sangat besar diantaranya adalah perselisihan. Dalam tulisan ini pun lebih tertuju pada hadis riwayat musim tentang ghibah dan mencari tau keshahihan hadits tersebut dan juga syarah hadis, walaupu pada dasarya ghibah itu haram tpi pada hadis tersebut terdapat perbolehan da tidakya. Penelitian ini menggunakan rieset perpustakaan secara fline dan online.
\end{abstract}

Kata kunci: Ghibah, Hadis, shahih 


\section{A. PENDAhuluan}

Setiap manusia dituntut untuk selalu berbuat baik, berbaik sangka, tidak menyakiti orang, ataupun menggunjing orang lain. Tapi pada kenyataannya Ghibah saat ini seperti sudah menjadi hal yang lumrah/biasa pada masyarakat sekarang, tidak jarang kita dapat menjumpai 2 atau pun sekumpulan orang yang sedang gosip/ghibah. Contoh kecilnya adalah ibu-ibu yang sedang membeli sayar dikomplek pasti ada saja yang dighibahkan dan lebih parahnya di dunia televisi sendiri ada acara-acara yang sengaja hanya untuk gosip para selebriti.

Ghibah adalah menceritakan seseorang yang tidak disukainya sehingga ini merupakan suatu perbuatan tercela dan dilarang dalam alquran da hadis

Padahal ghibah itu jelas dilarang dalam Q.S Al-Hujurat ayat 11-12. Pada makalah ini saya akan menjelaskan bagaimana ghibah dalam perefektif hadis

\section{B. PEMBAHASAN}

\section{Pengertian gibah dan bentuknya}

Secara etimoligi, Ghibah berasal dari kata ghaabaha yaghiibu ghaiban yang berarti ghaib, tidak hadir. Kata جَخ اغُّا akar kata Maqayis al-Lughah diartikan sebagai "sesuatu yang tertutup dari pandangan". Asal kata ini memberikan Pemahamaan unsur "ketidakhadiran seseorangee dalam ghibah, yakni orang yang menjadi objek pembicaraan. Kata ghibah dalam bahasa Indonesia mengandung arti umpatan, yang diarkan sebagai perkataan yang memburuk-burukkan orang. ${ }^{2}$

Ghibah secara termilogi yaitu menceritakan tentang seseorang yang tidak berada ditempat dengan sesuatu yang tidak disukainya. Baik menyebutkan aib

\footnotetext{
${ }^{1}$ Abu al-Husain Ahmad bin Faris bin Zakariya, Mu'jam al Lughah ( Beirut: Dar al-Fikr, 1999), hal. 340

${ }^{2}$ W.J.S. Poerwardarminta, Kamus Umum Bahasa Indonesia (Jakarta: Balai Pustaka, 2003), hal. 1336
} 
badannya, keturunannya, akhlaknya, perbuatannya, urusan agamanya, dan urusan duanianya $^{3}$

Sedangkan ulama memberikan ragam definisi. Di antaranya adalah:

- Imam al-Raghib mengatakan bahwa gibah adalah ,Seseorang menceritakan aib orang lain tanpa ada keperluan ${ }^{4}$

- Menurut Imam al-Ghazaly, gibah adalah ,menceritakan seseorang dengan sesuatu yang tidak disukainya andaikan hal itu sampai padanya ${ }^{5}$

- Imam Nawawi mendefinisikannya dengan menceritakan seseorang pada saat dia tidak ada dengan sesuatu yang tidak disukainya ${ }^{6}$

Pengertian di atas, dapat disimpulkan bahwa sesuatu obrolan dapat dikatakan gibah bila orang yang dibicarakan tidak ada dan obyek pembicaraan tentang kekurangan atau aib seseorang dan orang tersebut tidak rela dengan pembicaraan itu.

Ghibah terbagi menjadi 4 bentuk, yaitu $;^{7}$

- Dalam bentuknya sebagai kekufuran. Adapun ghibah dalam bentuk kekufuran, yaitu apabila ia berbuat ghibah pada seorang muslim (yang tidak berhak untuk di ghibah), maka kemudian dikatakan kepadanya: "jangan ber-ghibah!" (padahal dalam hatinya ia tahu bahwa dia sedang meng-ghibah,); Maka dia telah mengharamkan apa yang Allah haramkan, sedang barangsiapa yang menghalalkan apa yang telah Allah haramkan menjadikan (pelakunya) kafir.

- Dalam bentuknya sebagai kemunafikan. Adapun dalam bentuknya sebagai kemunafikan, yaitu ketika ia berbuat ghibah untuk orang tertentu tanpa

\footnotetext{
${ }^{3}$ Hasan Sa ecudi, Jerat-jerat Lisan ( Solo: Pustaka Arafah, 2003), hal 14.

${ }^{4}$ Ahmad ibn 'Ali ibn H\{ajar al-Asqalani, Fath al-Bari, Juz. XII (Beirut: Dar al-Fikr, 1414 H./1991 M.), h. 88.

${ }^{5}$ Abu Hamid Muhammad ibn Muhammad al-Gazali, Ihya' 'Ulum al-Din, Juz. II (Cet. I; Beirut: Dar al-Fikr, 1991M.), h. 338.

${ }^{6}$ Abu Zakariya Yahya ibn Syaraf al-Nawawi, Syarh al-Nawawi 'ala Sahih\} Muslim, Juz. XVI (Beirut: Dar al-Fikr, 1401 H./1981 M.), h. 142

${ }^{7}$ Muslich Shabir, Peringatan Bagi Orang-orang Yang Lupa (Semarang: CV. Toha Putra, 1993), hal. 333
} 
menyebut nama orang tersebut, tapi hal itu desebutkannya pada orang-orang yang mengenal dan mengetahui orang yang disebutnya tersebut sehingga mereka benar-benar tahu bahwa yang dimaksudkannya tersebut adalah "fulaan". Maka dia telah menggunjingnya, namun dia mengaggap dia terbebas dari itu, maka justru disinal kemunafikan tersebut.

- Dalam bentuknya sebagai maksiat Adapun ghibah dalam bentuknya sebagai maksiat yaitu, maka apabila seseorang mengghibahi seseorang dengan menyebut nama, dan dia mengetahui bahwa ia melakukan maksiat ( dengan ghibah tersebut) maka inilah merupakan perbuatan maksiat

- Dalam bentuknya sebagai sesuatu yang diperbolehkanAdapun bentuk keempat, yaitu meng-ghibah orang-orang yang faasiq yang terang-terangan menampakan kefasiqannya, atau para perayu kebid'ahan. Tetapi perkara ini kita tetap harus berhati-hati, jangan sampai hanya bedasarkan prasangka semata. Jikalau orang yang kita anggap masuk dalam kategori keempat ternyata sebenarnya tidak berhak di ghibah, maka terjerumuslah kita dalam dosa ghibah. Kemudian kalaupun orang tersebut boleh untuk di ghibah, maka cukup dijelaskan apa yang hendak dijelaskan.

\section{Gibah dalam persfektif hadis}

Posisi Hadis sebagai salah satu sumber hukum islam menjadi titik penting dalam pemaknaannya. Penjelasan gibah terdapat dalam salah satu hadis yg di riwayatkan imam muslim nomor 2589, yg berbunyi;

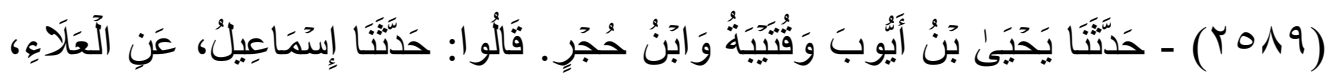

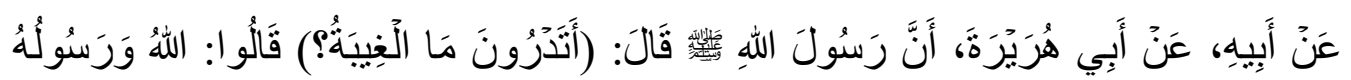

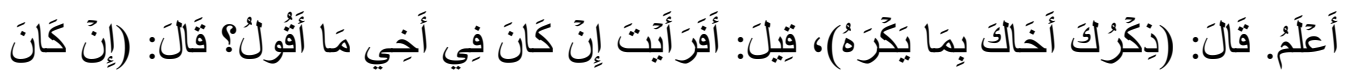

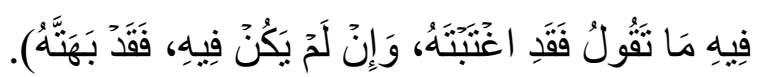


70. (2589). Yahya bin Ayyub, Qutaibah, dan Ibnu Hujr telah menceritakan kepada kami. Mereka berkata: Isma'il menceritakan kepada kami, dari Al'Ala', dari ayahnya, dari Abu Hurairah, bahwa Rasulullah shallallahu 'alaihi wa sallam bersabda, "Apakah kalian tahu gibah itu?"

Para sahabat menjawab, "Allah dan Rasul-Nya lebih tahu."

Beliau bersabda, "Gibah adalah engkau menyebutkan saudaramu dengan sesuatu yang tidak dia sukai.”

Ada yang bertanya, "Apa pendapat Anda apabila apa yang aku ucapkan memang ada pada diri saudaraku?"

Beliau bersabda, "Jika pada dirinya ada yang engkau ucapkan, maka engkau telah berbuat gibah kepadanya. Jika ternyata tidak ada pada dirinya, berarti engkau berkata dusta terhadapnya."

Berdasarkan Hadis di atas, ghibah diartikan menyatakan tentang sesuatu yang terdapat pada diri seseorang muslim di saat ia tidak berada di tempat, dan apa yang disebutkan memang ada pada orang tersebut tetapi ia tidak suka hal tersebut dinyatakan. Adapun jika yang disebutkan tidak ada padanya, berarti telah memfitnahnya. Dalam Hadis di atas sudah sangat jelas mengenai ghibah. Setelah mepelajari dan memahami Hadis di atas, dapat disimpulkan bahwa ghibah yaitu menyebutkan sesuatu yang sebenarnya tentang seseorang, baik tentang agamanya, akhlaknya, ataupun tentang yang lainnya, di saat orang tersebut tidak hadir atau tidak mendengarnya secara lansung, dan jika ia mengetahui tidak menyukainya.

Hadis ini menjadi referensi utama dalam pembahasan ini. Hadis ini dipandang tepat karena dapat dianalisis dengan dua sisi yang berbeda yaitu pro dan kontra terhadap gibah, sehingga antara yang pro danbkontra dapat menggunakan hadis tersebut sebagai hadis utama. Jika dibandingkan dengan 
hadis yang lain, hadis ini bisa mendefinisikan maksud dari gibah itu sendiri, sehingga dapat dipahami apa itu gibah . Hadis-hadis lain yang sejenis hanya memaparkan akibat yang diperoleh jika orang melakukan gibah .

Hakikat gibah kamu membicarakan saudaramu mengenai sesuatu yang ia tidak sukai. Dari proses tanya- jawab yang dilakukan Rasulullah saw dan sahabat dalam hadis ini adalah salah satu bentuk etika atau tata krama dalam majlis Rasulullah saw. Hadis di atas menjelaskan gambaran tentang gibah adalah pengungkapan yang dilakukan seorang muslim mengenai diri sesamanya muslim yang apabila didengar menimbulkan rasa benci dapat juga dimaknai gibah yaitu menyebutkan sesuatu yang terdapat pada diri seorang muslim, padahal ia tidak suka bila disebutkan. Berdasarkan uraian diatas dipahami gibah merupakanpengungkapan aib atau cacat seseorang baik yang dilakukan secara lisan, tulisan, isyarat maupun gerakan yang dapat dipahami maksudnya sebagai bentuk penghinaan atau merendakan derajatnya, dan apabila yang didengar atau diketahui oleh orang yang digunjing itu timbul rasa permusuhan, malu dan sebagainya. ${ }^{8}$

\section{Penilaian perawi pada hadis diatas}

Dari hadis diatas jika kita simpulka rantai sanadnya seperti ini;

(Rasulullah SAW. $\rightarrow$ Abu Hurairah $\rightarrow$ Abdurrahman bin Ya ${ }^{e e} k u b \rightarrow$ Al-Alaa ${ }^{e e}$ $\rightarrow$ Ismail $\rightarrow$ Ibnu Hujr, Qutaibah, dan Yahya bin Ayyub $\rightarrow$ Imam Muslim)

Berikut dibwah ini penilaian perawi-perawi tesebut; ${ }^{9}$

\section{- Abu Hurairah}

Abu Hurairah berasal dari kalangan sahabat. Nama lengkapnya adalah Abdurrahman bin Shakhr, sedangkan nama kuniyahnya adalah Abu Hurairah. Abu Hurairah dikenal dengan sebutan Abu al-Syam dan bergelar Abu Aswad.

\footnotetext{
${ }^{8}$ Musyfikah Ilyas, Ghibah Perspektif Sunnah Al-Qadau Volume 5 Nomor 1 Juni 2018) hal 153

${ }^{9}$ Muhammad Luthfi Dhulkifli,Pro-Kontra Gibah dalam Tinjauan Hadis dan Konteks Maraknya Perilaku Gosip, alquds, Volume 3, Nomor 1, 2019) hal 57-61
} 
Gelar tersebut diberikan oleh nabi Muhammad pada tahun 7 H/629 M. Disebutkan bahwa hadis yang diriwayatkan melalui jalur Abu Hurairah sebanyak 5374 hadis dengan lebih dari 800 perawi yang menerima hadis darinya. Abu Hurairah meriwayatkan hadis dari Nabi Muhammad SAW, Salman Al-Farisi, Zaid bin Tsabit, dan lain-lain. Murid-muridnya antara lain: Muslim bin Abdullah, Sulaiman bin Yasar Al-Hilali, Abu Tamim Az-Zuhri, Said bin Al Musayyab, Abu Ja ${ }^{e e} f a r$ Al-Anshari, dan lain-lain. Mengenai kualitasnya, jumhur ulama berpendapat bahwa semua rawi yang berasal dari kalangan sahabat adalah adil. Abu Hurairah wafat pada tahun $57 \mathrm{H}$. Imam Syafie $i$ menyatakan bahwa Abu Hurairah adalah orang yang paling banyak menghafal hadis di masanya.

- Abuhu (Ayahnya dari Al-Alaa')

Nama Lengkap beliau adalah Abdurrahman ibn Yaequb Al Juhaniy Al Madani dan tergolong dalam tabi'in kalangan pertengahan. Beliau banyak menghabiskan masa hidupnya di Madinah. Diantara guru-gurunya adalah: Abu Hurairah, Abdurrahman ibn Yamin al Madani, Abdullah ibn Abbas, Abdullah ibn Umar ibn Khattab, Abdul Malik ibn Naufal ibn Al Haris. Beliau juga memiliki sejumlah murid dalam kajian hadis, diantaranya: Anaknya (Al Alaa ibn Abdurrahman ibn Ya $\left.{ }^{e e} q u b\right)$, Salim Abu An Nadhr, Umar ibn Hafs ibn Dzakwan. Mengenai penilaian terhadap beliau, Ibnu Hibban mnganggapnya sebagai seorang yang Tsiqqoh, Al-Ijli juga menyatakan Tsiqqoh, dan Imam an-Nasa ${ }^{e i}$ menyebut tidak ada cacat.

\section{- Al-Alaa'}

Nama lengkapnya adalah Al-Alaa ${ }^{e e}$ ibn Abdurrahman Al Hiraqiy. Al-Alaa ${ }^{\text {ee }}$ wafat pada tahun $130 \mathrm{H}$. Nama kuniyahnya adalah Abu Syubul dan tinggal di Madinah. Guru-guru beliau dalam mendapatkan hadis diantaranya: Ibnu umar,Anas, Abbas ibn Sahl ibn Saed, Ayahnya (Abdurrahman bin Yaeckub), Ali ibn Majidah Nuaim Al Mujmir, Sa ${ }^{e e}$ ibn Ka ${ }^{e e} a b$ ibn Malik. Adapun murid- 
murid yang belajar secara langsung meliputi: Ismail ibn Ja Jar ibn Abi Katsir, Muhammad

ibn Ajlan, Anaknya (Syibli), Ibn Ishaq, Ibnu Juraij, Ubaidillah ibn Umar, Hafsh ibn Maysarah. Mengenai al-Alaa ${ }^{e e}$, Abdullah ibn Ahmad menilai sebagai Tsiqqoh, tidak pernah mendengar tentang keburukannya, Hal demikian juga diungkapkan oleh Abu Hatim dengan menyebut sebagai Shalih, Tsiqqoh, Ibnu Hibban mengatakanTsiqqoh, begitu pula dengan Ibnu Said dan Tirmidzi.

- Ibn Hujr.

Nama Lengkapnya Ali ibn Hujr ibn Iyas ibn Maqathil ibn Mukhadisy AsSa ${ }^{e e}$ diy. Beliau dilahirkan pada $154 \mathrm{H}$ dan memiliki masa hidup hampir 100 tahun saat wafat $253 \mathrm{H}$. Nama kuniyahnya adalah Abu Al Hasan dan beliau banyak menghabiskan masa hidupnya di Baghdad. Para ulamae tempatnya belajar hadis adalah: Ismail ibn Jaefar, Ismail ibn Ulayyah, Ishak ibn Najih, Al Malati, Ismail ibn Ayasi. Beliau juga memunculkan murid-murid yang kemudian sangat mashur dalam bidang hadis semisal: Bukhari, Muslim, Tirmidzi, Nasai, Ahmad ibn Muslim Al Abbari Al Baghdadi, Abu Ishak Ibrahim ibn Ismail Al Ambary. Abu Ali Muhammad ibn Ali ibn Hamzah Al Marwazi memuji beliau sebagai Fadhi, Hafidz, an-Nasai menyebutnya sebagai Tsiqqoh, Ma"mun, Hafid, Shoduq, sementara Abu Bakar Al-Khatib mengatakan Shodu, Hafidz, Mutqan/diyakini keshalihannya.

- Qutaibah

Nama lengkap dari Qutaibah adalah Qutaibah ibn Said. Beliau lahir pada $148 \mathrm{H}$ dan wafat $240 \mathrm{H}$. Nama kuniyahnya adalah Abu Raja ${ }^{e}$. Diantara guru-

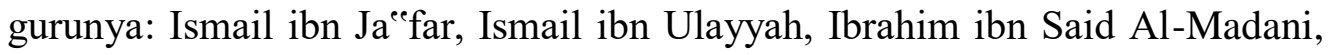
Ismail ibn Abi Awyus, Abi Dhomiroh, Anas ibn Iyyadh, Abu Ayub ibn Jabir.

Diantara para ulamae yang belajar kepada Qutaibah adalah: Yahya Ibrahim ibn ishaq, Ahmad ibn Hanbal, Ahmad ibn Said Ad-Darimi, Ahmad ibn Sayar Al-Maruzi, Ahmad ibn Abdurrahman, Abu Hamid Ahmad ibn 
Qudamah ibn Muhammad ibn Abdillah. Adapun mengenai kualitas pribadinya, menurut $\mathrm{Abu}$

Bakar Al-Asram: Pujian atasnya, Ahmad ibn Abi Haistam dari Yahya ibn Ma ${ }^{e e}$ in dan Abu Hatim dan Nasa ${ }^{e c} i$ menyatakan Tsiqqoh, an-Nasa ${ }^{e e} i$ dan Ibn Kharas menyebut sebagai Shoduq/jujur.

- Yahya ibn Ayub

Beliau memiliki nama lengkap Yahya ibn Ayub Al-Maqabiry. Beliau dilahirkan pada $157 \mathrm{H}$ dan wafat pada $233 \mathrm{H}$. Nama kuniyahnya Abu Zakariyae. Para guru yang mengajarkan hadis padanya mencakup: Ismail ibn Ibrahim ibn Sulaiman al-Muaddab, Ismail ibn Ja"efar al-Madani, Ismail ibn Ulayyah, Hasan ibn Karmani, Hamid ibn Abdurrahman, Ismail bin Jaefar. Sementara murid-murid yang belajar kepadanya meliputi: Muslim, Ahmad ibn Hasan ibn Abdul Jabar Ash-Shufi, Abu Daud, Ahmad ibn Hanbal, Abu Bakar Ahmad ibn Ali ibn Said, al-Qhadi, Ahmad ibn Ali. Dikatakan oleh Ibnu Qoni jika beliau adalah Tsiqqoh, Al-Husain ibn Muhammad ibn Al-Fahm menyebut Wara ${ }^{e /}$ lebih mengutamakan urusan akhirat, Tsiqqoh, Abu Hasan Al-Maymun menilainya Sholih/jujur begitu pula Ali Ibn Al-Madini dan Abu Hatim, Abu Syuaib Al Haron memuji dengan julukan Hamba Pilihan Allah, terakhir Musa ibn Harun ibn Abdillah Sarij ibn Yunus menganggapnya sebagai Sholih.

- Imam Muslim

Imam Muslim memiliki nama asli Muslim al-Hajjaj al-Qusyairi alNaisaburi. Beliau lahir dan wafat di kota Naisabur pada tahun 204 H dan 261 H. Meskipun hanya memiliki usia yang tidak terlalu panjang, Imam Muslimmenunjukkan bahwa dirinya memang sosok yang penting dalam kajian hadis. Daya hafalnya yang tinggi membuatnya mampu mengarang sebuah kitab yang masih sangat penting hingga saat ini. Sepanjang hidupnya, Imam Musli telah belajar dengan banyak guru sperti: Yahya bin Ayyub, Qutaibah, Ibnu Hujr, Shaq bin Rohawayh, Muhammad bin „Amr, dan Bukhari. Tidak hanya itu, Imam Muslim juga memiliki sejumlah murid-murid seperti: Yahya 
bin Sha"id,Muhammad bin Makhlad, Muhammad bin Ishaq bin Khuzaimah, Muhammad bin Abdul wahhab al-Farro ${ }^{\text {ee }}$.

Dari sanad hadis tentang gibah tersebut memenuhi syarat keshahihan sanad. Hal ini dikarenakan seluruh syarat keshahihan sebuah sanad telah terpenuhi. Syarat-syarat keshahihan sanad hadis gibah tersebut ditunjukkan melalui ketersambungan sanad (ittishal al-sanad) dengan adanya jalur runtut antar perawi dari generasi ke generasi melalui hubungan sebagai guru dan murid; para perawinya kredibel (tsiqqahu al-ruwah) yang terlihat dari penilaian yang positif terhadap seluruh perawi tanpa ada yang menilai sebagai sosok yang cacat; serta terakhir adalah intelektualitas perawi (dhabtu alruwah) melalui kemampuan mereka dalam mengingat hadis.

\section{KESIMPULAN}

Ghibah yaitu menceritakan tentang seseorang yang tidak berada ditempat dengan sesuatu yang tidak disukainya. Baik menyebutkan aib badannya, keturunannya, akhlaknya, perbuatannya, urusan agamanya, dan urusan duanianya.

Posisi Hadis sebagai salah satu sumber hukum islam menjadi titik penting dalam pemaknaannya. Penjelasan gibah terdapat dalam salah satu hadis yg di riwayatkan imam muslim nomor 2589

Hadis ini menjadi referensi utama dalam pembahasan ini. Hadis ini dipandang tepat karena dapat dianalisis dengan dua sisi yang berbeda yaitu pro dan kontra terhadap gibah, sehingga antara yang pro danbkontra dapat menggunakan hadis tersebut sebagai hadis utama. Jika dibandingkan dengan hadis yang lain, hadis ini bisa mendefinisikan maksud dari gibah itu sendiri, sehingga dapat dipahami apa itu gibah. Hadis-hadis lain yang sejenis hanya memaparkan akibat yang diperoleh jika orang melakukan gibah .

Dari hadis diatas jika kita simpulka rantai sanadnya seperti ini; 
(Rasulullah SAW. $\rightarrow$ Abu Hurairah $\rightarrow$ Abdurrahman bin Ya ${ }^{e e} k u b \rightarrow$ Al-Alaa ${ }^{e e}$ $\rightarrow$ Ismail $\rightarrow$ Ibnu Hujr, Qutaibah, dan Yahya bin Ayyub $\rightarrow$ Imam Muslim)

Dari sanad hadis tentang gibah tersebut memenuhi syarat keshahihan sanad. Hal ini dikarenakan seluruh syarat keshahihan sebuah sanad telah terpenuhi. Syarat-syarat keshahihan sanad hadis gibah tersebut ditunjukkan melalui ketersambungan sanad (ittishal al-sanad) dengan adanya jalur runtut antar perawi dari generasi ke generasi melalui hubungan sebagai guru dan murid; para perawinya kredibel (tsiqqahu al-ruwah) yang terlihat dari penilaian yang positif terhadap seluruh perawi tanpa ada yang menilai sebagai sosok yang cacat; serta terakhir adalah intelektualitas perawi (dhabtu al-ruwah) melalui kemampuan mereka dalam mengingat hadis.

\section{DAFTAR PUSTAKA}

Abu al-Husain Ahmad bin Faris bin Zakariya, Mu'jam al Lughah ( Beirut: Dar alFikr, 1999), hal. 340

W.J.S. Poerwardarminta, Kamus Umum Bahasa Indonesia (Jakarta: Balai Pustaka, 2003), hal. 1336

Hasan Saee udi, Jerat-jerat Lisan ( Solo: Pustaka Arafah, 2003), hal 14.

Ahmad ibn 'Ali ibn H\{ajar al-Asqalani, Fath al-Bari, Juz. XII (Beirut: Dar Fikr, 1414 H./1991 M.), h. 88.

Abu Hamid Muhammad ibn Muhammad al-Gazali, Ihya' 'Ulum al-Din, Juz. II (Cet. I; Beirut: Dar al-Fikr, 1991M.), h. 338.

Abu Zakariya Yahya ibn Syaraf al-Nawawi, Syarh al-Nawawi 'ala Sahih\} Muslim, Juz. XVI (Beirut: Dar al-Fikr, 1401 H./1981 M.), h. 142

Muslich Shabir, Peringatan Bagi Orang-orang Yang Lupa (Semarang: CV. Toha Putra, 1993), hal. 333

Musyfikah Ilyas,Ghibah Perspektif Sunnah Al-Qadau Volume 5 Nomor 1 Juni 2018) hal 153 
Muhammad Luthfi Dhulkifli,Pro-Kontra Gibah dalam Tinjauan Hadis dan Konteks Maraknya Perilaku Gosip, alquds, Volume 3, Nomor 1, 2019) hal 57-61 